TECHNICAL NOTE (TIGG-09/02/90-TN-1)

\title{
Simple Method for Obtaining Intact Oligosaccharides from Glycosphingolipids by Endoglyooceramidase
}

\author{
Makoto Ito \\ Laboratory of Glycoconjugate Research, \\ Mitsubishi Kasei Institute of Life Sciences, \\ 11, Minamiooya, Machida-shi, Tokyo 194, Japan, FAX: 81-427-29-1252
}

Although ozonolysis and periodate oxidations have been conducted to obtain intact oligosaccharides from glycosphingolipids, these methods are not suitable for preparing oligosaccharides from small sample quantities and they require much time. This paper presents a simple and reprodudiple method for obtaining with high recovery and reproducibly intact oligosaccharides from glycosphingolipids by using endoglycoceramidase (EGCase)[13].

EGCase is the enzyme which cleaves the linkage between the oligosaccharide and ceramides of various glycosphingolipids and its specificity is shown in Table 1. Two major molecular species of EGCase (EGCase I, II) differing in specificity have been isolated from the culture fluid of Rhodococcus sp. and were found capable of hydrolyzing the glucosylceramide linkages of the ganglio, lacto, and globo-type glycosphingolipids to afford intact oligosaccharides and ceramides. Globo-type glycosphingolipids were strongly resistant to hydrolysis by EGCase II compared to EGCase I. Neither could hydrolyze cerebrosides or sulfatides. The commercial preparation of EGCase (Genzyme Co., Boston, U.S.A.) is a mixture of EGCase I and II.

Glycosphingolipids were dissolved in $10 \mathrm{mM}$ sodium acetate buffer $\mathrm{pH} 5.0$ containing $0.4 \%(\mathrm{~W} / \mathrm{V})$ of Triton $\mathrm{X}-100$ at the concentration of $1 \mathrm{mM}$ and subjected to sonic-treatment for $1 \mathrm{~min}$.
When difficult to dissolve the sample should be heated. As a standard condition, a reaction mixture was used containing $50 \mathrm{n}$ mol of various glycosphingolipids, $10 \mu \mu \mathrm{g}$ of $\mathrm{BSA}$ and 1.5 milliunits of EGCase in $50 \mu \mathrm{l}$ of $10 \mathrm{mM}$ sodium acetate buffer, pH 5.5, containing $0.4 \%(\mathrm{~W} / \mathrm{V})$ of Triton $\mathrm{X}-100$. Condition II in Table 1 indicates the extent of hydrolysis of glycosphingolipids when 1.5 milliunits of the enzyme is incubated with $50 \mathrm{n} \mathrm{mol}$ of appropriate glyoosphingolipid at $37^{\circ} \mathrm{C}$ for $16 \mathrm{~h}$. Except for globo-type glycosphingolipids, each glycosphingolipid was hydrolyzed under this condition (II) as shown in Table 1. 3-5 times the amount of enzyme was necessary for complete hydrolysis of globo-type glyoosphingolipids to occur.

The enzyme may be stored at $-20^{\circ} \mathrm{C}$ for 6 months without detectable loss of activity. However, repeated freezethawing results in marked loss of activity.

To determine the extent of hydrolysis of glycosphingolipids by EGCase, a reaction mixture corresponding to $10 \mathrm{n}$ mol of each glycosphingolipid was freeze-dried, dissolved in 50 \& methanol, and applied onto an HPTLC plate (Precoated Silica Gel HPTLC plates, Merck). The plate was developed by n-butanol/acetic acid/water $(2 / 1 / 1, v / v)$ as the developing solvent. The oligosaccharide migrated slower than the original glycosphingolipid in this solvent system and was visualized 


\section{テクニカルノート (TIGG-09/02/90-TN-1)

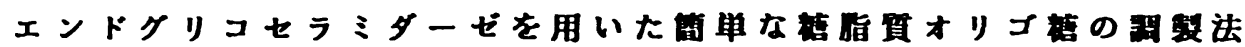

\section{伊東 信}

糖脂質からオリゴ糖を調製する方法として は従来オソン分解や過ヨウ索酸酸化法が用い られてきた。これらの化学的な方法は収率の 点で問題があるばかりでなく、操作る煩雑で 時間を要する。また、微量の糖脂質からオリ ゴ糖を得る方法としても不道当である。エン ドグリコセラミダーゼ（EGCase）という榶脂 質のオリゴ糖鎖とセラミドの間を加水分解す る酥素[Methods in Enzymology (1990) 179. 488-496; J. Biol. Chem. (1986) 261. 14278-14282；(1989）264，9510-9519]を用い た簡単な榶脂質オリゴ榶の調製法を紹介する。

この䣼はセレブロシド、スルファチドを 除く殆どすべての榶脂質に作用し、完全な形 の榶鎖を遊雒することができる。EGCaseの特 異性をTable 1.にまとめる。現在、市眅され ている醉䒺（日本の場合、生化学工業その他 の国ではGenzyme社）はこの表に示されている EGCase I と II の混合物である。糖脂質を0. $4 \%$ $(W / V)$ トリトンX-100含有 $10 \mathrm{mM}$ 酢酸緩衙液 pH5.0に1マイクロモル/mlの灌度で溶解させ、 ソニヶーターで1分間超音波処理する。溶け にくいサンプルは加熱する。糖脂質からオリ ゴ糖を得る目的の実験では糖脂質の漕度は厳 密ではなく一応の目安と考えていただきたい。 市販のEGCaseは凍結乾燥標品なので上記緩衙 液を加えて溶解する。醉素は必要量ずつ分注 して $-20^{\circ} \mathrm{C} て ゙$ 保存すると少なくとも半年間は使 用できる。凍結一融解を絽り返すと失活する ことがあるので注意を要する。50ナノモルの 糖脂質を加水分解する時に、1.5 ミリ単位の EGCaseを加え、37ㄷ C 16 時間反机させたとき の糖脂質の分解率をTable 1. のcondition II の項に示した。グロボ系列の糖脂質を除いて、
この条件下で表に示した糖脂質を完全に分解 することができる。グロボ系列の糖脂質は EGCaseによって分解されにくいのて、3〜 5倍 量の醉䒺を加える必要がある。高度に精製し たEGCaseを用いる時はEGCaseの安定化のため に反応液に0. $2 \mathrm{mg} / \mathrm{m} 1$ の濃度になるようにBSAを 加える必要があるが、市販のEGCaseを使用す ろ時には必ずしもその必要はない。

榶脂質のEGCaseによる分解の程度を知るた めにはHPTLC（シリカゲル60HPTLCプレート、 メルク社）で調べのが簡単である。10ナノ モル相当の糖脂質分解物をHPTLCにのせ、nーブ タノール/酢酸/水 $(2 / 1 / 1, v / v) て ゙$ 開する。 発色はオルシノールー硫酸法で行う。オリゴ 詰は糖脂質よりも移動度が革いのて、、糖脂質 と簡単に区別がつけられる。市販のEGCase標 品にはエキソグリコシダーゼおよびシアリダ 一ゼは含まれていないので、糖脂質から完全 な形のオリゴ榶が得られる。つまり、セラミ ド部分の多様性がなくなるので、たとえ糖脂 質のスポットは複数でも試料の榶脂質標品の 糖鎖が単一であれば、単一のスポットが得ら れるはずである。また、得られたオリゴ糖を FAB-MSにかけ分子量から目的のオリゴ糖が得 られたかどうか確認することができる。この 方法はEGCase処理によって同時に得られるセ ラミドにも適枕できる[実験医学（1987）6567. Fukaya et al. Biochim. Biophys. Acta (1989) 1004, 108-116]。

反底液からオリゴ糦を単離するために、反 応液に5倍量のクロロホルムノメタノール(2) $1, v / v)$ 加えForch分眍をする。上層を乾固して オリゴ糖画分として使用する。また、下層か らは各々の榶脂質に対応したセラミドが得ら 
by orcinol- $\mathrm{H}_{2} \mathrm{SO}_{4}$. The oligosaccharides as well as ceramides were also analyzed by FAB-MS $[4,5]$.

Following the hydrolysis of glycosphingolipids, the reaction mixture was patitioned with 5 volumes of chloroform/methanol $(2 / 1, v / v)$. The upper layer obtained was dried under a stream of $\mathrm{N}_{2}$-gas, and used for glycosphingolipid-derived oligosaccharides. The ceramides corresponding to each glycosphingolipid could be obtained from the lower phase. SEP-PAK (Millipore Waters Associate) also facilitates obtaining oligosaccharides from the reaction mixture. The reaction mixture was applied onto SEP-PAK previously equilibrated with methanol/water $(1 / 1$, $\mathrm{v} / \mathrm{v})$. The oligosaccharides were passed through SEP-PAK, while ceramides and glycosphingolipids undigested by EGCase were adsorbed onto SEP-PAK. In the case of small quantity samples, some of the SEP-PAK should be taken from the cartridge and placed in a millipore filtration tube (Ultra free C3LGC, Millipore Co.). In this study, after being kept at room temperature for 30 min with shaking, the filtration tube was inserted into an Eppendorf centrifugation tube $(1 \mathrm{ml})$ and centrifuged at 7,000 r.p.m. for $20 \mathrm{~min}$. The filtrates obtained were dried under a stream of $\mathrm{N}_{2}$-gas and used for oligosaccharides. This method could be used to clean oligosaccharides obtained by the Folchpatition method described above.

Oligosaccharides obtained may be covalently linked to the TLC-plates as a result of reductive amination with $\mathrm{NaCNBH}_{3}$ [6] or attached to protein by the heterobifunctional cross linker, succinimidyl 4-N-maleimidomethyl cyclohexane-1-carboxylate (SMCC) [7]. The later method was found applicable for obtaining neoganglioproteins from the cell surface using various oligosaccharides from glycosphingolipids as described in HOT PAPER 2 of this issue.

Oligosaccharides released by the enzyme from glycolipids were derivatized with aminobenzoic acid ethylester ( $A B E E$ ) and analyzed by HPLC on Amide 80 and C4 silica columns [8]. Individual oligosaccharide-ABEE derivatives were successfully separated without any overlapping on the columns, thus allowing the qualitative and quantitative analyses of glyoosphingolipids in the form of oligosaccharides. This method is applicable to the analysis of oligosaccharides regardless of their origin.

\section{References}

1. Ito, M., and Yamagata, T. (1986) J. Biol. Chem. 261, 14278-14282

2. Ito, M., and Yamagata, T. (1989) J. Biol. Chem. 264, 9510-9519

3. Ito, M., and Yamagata, T. (1990) Methods in Enzymol. 179, 488-496

4. Ito, M., and Yamagata, T. (1987) Experimental Medicine (Jikken Igaku), 65-67

5. Fukaya, N., et al. (1989) Biochim. Biophys. Acta 1004, 108-116

6. Higashi, H., et al. (1987) J. Biochem. 102, 291-296

7. Pacuszka, T., and Fishman, P.H. (1990) J. Biol. Chem. 265, 76737678

8. Higashi, H., et al. (1990) Anal. Biochem. 186, $355-362$ 
れる。反液からオリゴ榙を得る方法として SEP-PAK (Millipore Waters Associate) b利

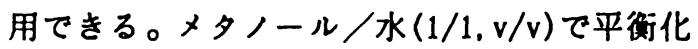
したSEP-PAKに反底液を通す。セラミドと末反 応の糖脂質は吸着され、オリゴ榶は溶出され る。Forch分眍で得たオリゴ楉の精製にもこの 方法は利用できる。試料が少量の時にはSEPPAKの樹脂をカートリッジから出して遠心ろ過 チューブ（ウルトラフリーC3LGC、ミリポア社） の上に試料とともにのせ、室温で30分間時々 摫捧しながら放置した後、ろ過チューブこと エッペンドルフチューブに入れて、7,000回転 で20分間遠心してろ過液をとる。

このようにして得られたオリゴ糖はTLCで展 開分離してから這元的アミノ化でTLC上に結合 させ、免疫染色を行うことるできるし [Higashi et al. J. Biochem. (1987) 102.
291-296]、今回のHot Paperで紹介したように タンパク質に結合させてネオガングリオプロ テインを作ることもできる[Pacuszka and Fishman, J. Biol. Chem. (1989) 265, 7673 -7678]。後者の方法は細胞表層のタンパク質 にオリコ糖を直接導入できる方法として注目 される。

棺脂質から得られるオリゴ糖をABEE（アミ ノエチル安息香酸）で誘導体にした後、HPLC カラムで分離分析し、糖脂質そのままの形で の分析に代えようという試みすおる[Higashi et al. Anal. Biochem. (1990) 186, 355362]。これはABEE-オリゴ榶がAmide80，C4 リカカラム上で互いに重ならず展開分離でき るという技術に基いている。糖脂質オリゴ糖 に限らず応用できる方法である。

Table 1. Specificity of Endoglycoceramidase

\begin{tabular}{|c|c|c|c|c|c|c|}
\hline \multirow{3}{*}{$\begin{array}{l}\text { Class } \\
\text { Ganglio } \\
\text { series }\end{array}$} & \multirow{2}{*}{\multicolumn{2}{|c|}{ Substrate }} & \multicolumn{2}{|c|}{$\begin{array}{l}\text { Hydrolysis } \\
\text { Enzyme I } \\
\text { Condition b) }\end{array}$} & \multicolumn{2}{|c|}{$\begin{array}{l}\text { Extent }(8)^{a)} \\
\text { Enzyme II } \\
\text { Condition }\end{array}$} \\
\hline & & & & & I & II \\
\hline & NeuAc $\alpha 2$ & GalB1-3GalNACB1-4 (NeUACQ2 -3) GalB1-4GlCB1-1 Cer & 15.5 & 100 & 16.3 & 100 \\
\hline & GM1a & GalB1-3GalNACB1-4(NeuACa2-3) GalB1-4GlCB1-1Cer & 47.9 & 100 & 37.9 & 100 \\
\hline & QM3 & NeUAC 2 2-3GalB1-4GICB1-1Cer & 17.8 & 100 & 84.9 & 100 \\
\hline & Asialo GM1 & GalB1-3GalNACB1-4GalB1-4GlCB1-1Cer & 71.9 & 100 & 65.1 & 100 \\
\hline Globo & Forssman $\left(\mathrm{Gb}_{5} \mathrm{Cer}\right)$ & GalNACa1-3GalNACB1-3Gala1-4GalB1-4G1CB1-1Cer & 4.5 & 87.9 & 0.1 & 8.9 \\
\hline & Globoside $\left(\mathrm{Gb}_{4} \mathrm{Cer}\right)$ & GalNACB1-3Gala1-4Ga1B1-4GlCB1-1Cer & 1.7 & 87.3 & 0.1 & 5.3 \\
\hline $\begin{array}{l}\text { Gala } \\
\text { series }\end{array}$ & Neogalatriaosylceramide (TGC) & GalB1-6GalB1-6GalB1-1Cer & 0 & 0 & 0 & 0 \\
\hline & Cerebroside & GalB1-1Cer, GlcB1-1Cer & 0 & 0 & 0 & 0 \\
\hline & Sulfatide & $\mathrm{HSO}_{3}-3 \mathrm{Gal} \mathrm{B1}-1 \mathrm{Cer}$ & 0 & 0 & 0 & 0 \\
\hline
\end{tabular}

a) Hydrolysis extent was calculated by the Assay II described in Experimental Procedure.

b) Condition I, $0.3 \mathrm{milli}$ unit of the enzyme was incubated with appropriate substrates at $37^{\circ} \mathrm{C}$ for $2 \mathrm{~h}$. Condition II, 1.5 mill1 units of the enzyme was incubated with appropriate substrates at $37^{\circ} \mathrm{C}$ for $16 \mathrm{~h}$. 